\title{
SISTEM INFORMASI PENGGAJIAN (STUDI KASUS: KANTOR RATONA TELEVISI PALOPO)
}

\author{
Ahmad Ali Hakam Dani ${ }^{1)}$, Feby Fadillah Kariadi ${ }^{2)}$ \\ 1) Dosen Program Studi Teknik Informatika Universitas Andi Djemma \\ ${ }^{2)}$ Program Studi Teknik Informatika Universitas Andi Djemma \\ 1)ahmad.ali@unanda.ac.id \\ 2)febyfadillah02@gmail.com
}

\begin{abstract}
Abstrak
Penelitian ini merupakan penelitian dengan tujuan untuk membangun sistem informasi penggajian karyawan di Kantor Ratona Televisi Palopo yang terkomputerisasi secara online, efektif, bermanfaat dan mempermudah pengolahan data penggajian. Penelitian ini dilakukan dengan metode pengumpulan data yang terdiri atas studi kepustakaan, studi literatur, dan studi lapangan dengan melakukan observasi dan wawancara. Pengembangan sistem pada penelitian ini menggunakan metode Rapid Application Development, yang tahapan-tahapannya meliputi: Scope Defenition, Analysis, Design, dan Implementation. Dalam membangun sistem informasi menggunakan Unified Modelling Language (UML), bahasa pemrograman PHP, database MySQL, dan XAMPP, serta sistem informasi penggajian yang dibuat ini berbasis website. Pada tahap validasi, sistem yang dibuat divalidasi oleh para ahli dan responden dari pihak Ratona TV. Berdasarkan hasil pembahasan pengembangan sistem informasi penggajian yang telah dilakukan, maka hasil yang didapatkan yaitu sistem informasi penggajian yang dibuat terdiri dari proses pengolahan data master, absensi, dan penggajian yang disertai dengan laporanlaporan yang berkaitan dengan penggajian. Sebagai kesimpulan bahwa sistem informasi penggajian yang dibuat telah terkomputerisasi secara online, efisien, bermanfaat dan mempermudah pengolahan data penggajian. Selain itu sistem informasi penggajian yang dibuat tergolong praktis bagi karyawan Ratona TV Palopo.
\end{abstract}

Kata kunci: Sistem Informasi Penggajian, Rapid Application Development, Unified Modelling Language, PHP, MySQL, Website.

\section{PENDAHULUAN}

Perkembangan ilmu pengetahuan dan teknologi pada saat sekarang ini mempunyai peranan yang sangat penting, salah satunya di bidang komputer. Terbukti dengan banyaknya lembaga/instansi pemerintah yang menggunakan sistem komputerisasi sebagai alat bantu untuk meningkatkan kreatifitas dan aktifitas para pegawai sehingga memiliki skill yang bagus dan menjadikan lembaga/instansi pemerintah memiliki kompetensi yang tinggi. Ratona Televisi adalah lembaga penyiaran yang bergerak dalam bidang pertelevisian lokal yang dibawahi oleh bagian Hubungan Masyarakat (HUMAS) Pemerintah Kota Palopo.

Sistem penggajian merupakan sistem pembayaran atas penyerahan jasa yang dilakukan oleh karyawan yang mempunyai jenjang jabatan dan dibayarkan per bulan. Menurut Jame A.Hall (Zulnalis, 2016: 3), gaji adalah balas jasa yang dibayarkan secara periodik kepada karyawan tetap serta mempunyai jaminan yang pasti. Berdasarkan hasil observasi, gaji para karyawan Ratona TV pada umumnya akan dibagikan pada setiap awal bulan, hal ini berpacu pada sistem Pemerintahan yang menggaji pegawai disetiap awal bulan. Dengan demikian, kesibukan ataupun kegiatan yang dilakukan oleh bagian keuangan pada saat itu adalah: merekap absensi karyawan Ratona TV selama sebulan full, menghitung banyaknya berita yang dibuat oleh karyawan, membuat rekapitulasi gaji dan harus disetujui oleh Direktur, mencairkan gaji karyawan di Badan Pengelolaan Keuangan Dan Aset Daerah (BPAKD) Kota Palopo, dan memberikannya kepada pegawai Bank untuk ditransferkan kepada rekening semua karyawan. 
Sistem administrasi penggajian di atas sebenarnya sudah baik dan sudah memenuhi persyaratan prosedur penggajian. Akan tetapi dikarenakan sistem tersebut masih dikerjakan secara manual maka berbagai persoalan pada akhirnya muncul, seperti: (a)Waktu yang diperlukan untuk pembuatan berbagai macam laporan yang berhubungan dengan sistem penggajian menjadi lama. (b)Informasi yang disajikan menjadi kurang teliti misalnya banyak dijumpai data ganda maupun data yang kurang lengkap. (c)Sering terjadi masalah karena salah perhitungan gaji. (d)Pembuatan laporan pertanggung jawaban gaji kadang menjadi sulit karena beberapa data yang telah ditulis di kertas telah hilang dan harus dibuat kembali.

Berdasarkan hal diatas, perlu diadakan pembenahan yang kompleks dan teratur didalam manajemen penggajian yang lebih baik lagi. Salah satu alat yang dapat digunakan untuk memperbaiki aktivitas penggajian tersebut adalah dengan menciptakan suatu sistem informasi penggajian yang benar-benar efesien dan cepat karena hal ini sangat penting untuk menghindari kesalahan sistem informasi penggajian yang diinginkan pada Kantor Ratona TV.

\section{METODOLOGI PENELITIAN}

Alur penelitian ini dapat dilihat pada diagram alir berikut ini:

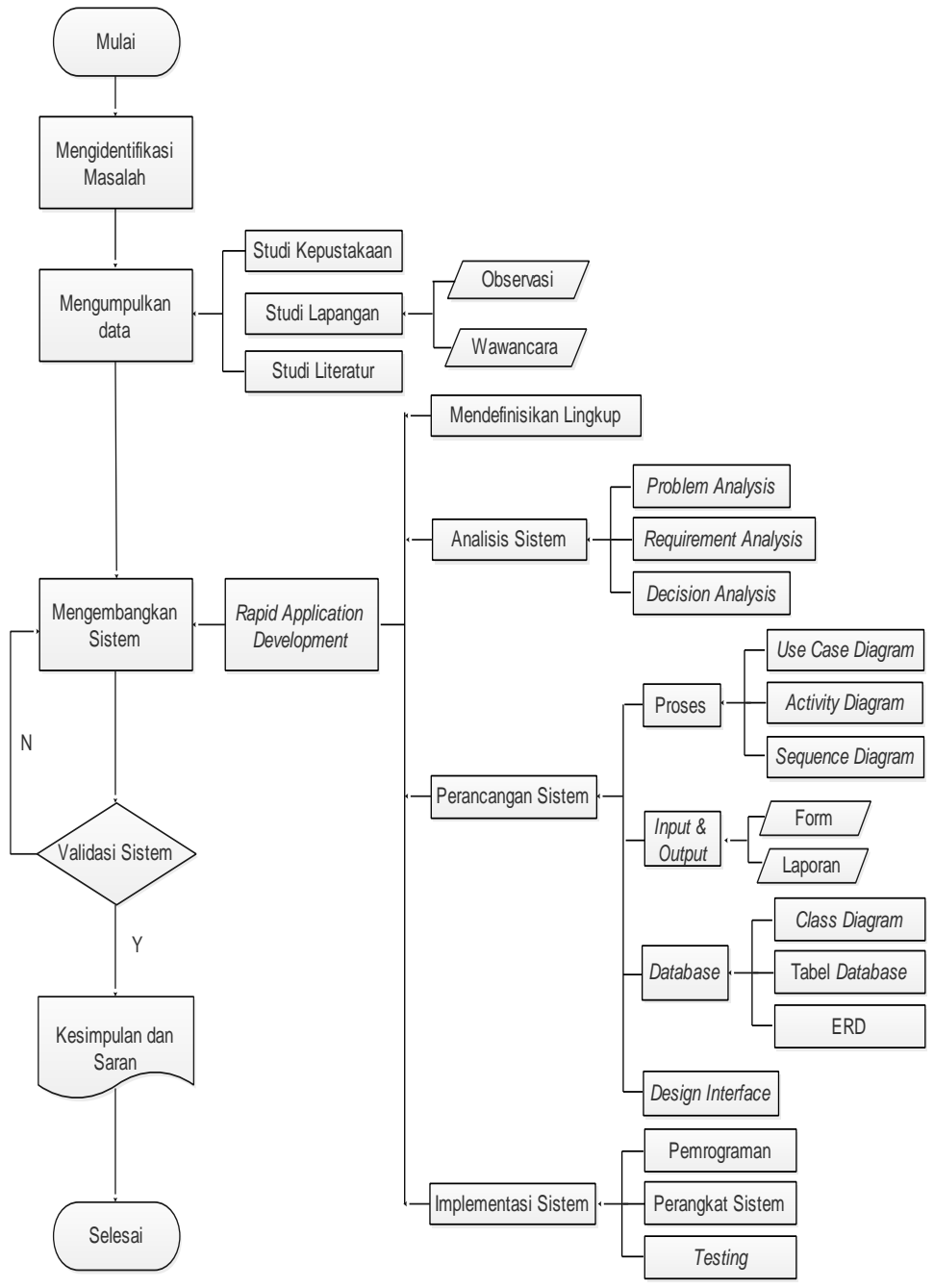

Gambar 1. Diagram Alir Penelitian 
Penelitian ini dimulai dengan mengidentifikasi permasalahan tentang penggajian di Kantor Ratona TV kemudian mengumpulkan data-data yang diperlukan. Setelah semua pengumpulan data telah selesai, maka tahap selanjutnya adalah melakukan tahap pengembangan sistem dengan menggunakan pendekatan Rapid Application Development (RAD), yang tahapnya terbagi menjadi empat bagian sebagai berikut: (1)Mendefinisikan lingkup dimana peneliti menentukan ruang lingkup pengembangan sistem dan mengidentifikasi kebutuhan sistem informasi, (2)Analisis sistem yang sedangkan berjalan pada Ratona TV lalu memberikan usulan terhadap sistem tersebut, (3) design, yang di dalamnya termuat diagram-diagram UML, dan (4)Implementasi, dimana peneliti melakukan membangun sistem dengan menggunakan bahasa pemrograman PHP dan database MySQL. Kemudian melakukan testing terhadap sistem yang telah dibangun. Setelah semua tahapan pengembangan sistem telah selesai, sistem informasi yang ada akan divalidasi, dan terakhir peneliti akan memberikan kesimpulan dan saran terhadap penelitian ini.

\section{HASIL DAN PEMBAHASAN}

Sistem Informasi yang Diusulkan

Adapun prosedur dari perancangan sistem yang diusulkan adalah sebagai berikut:

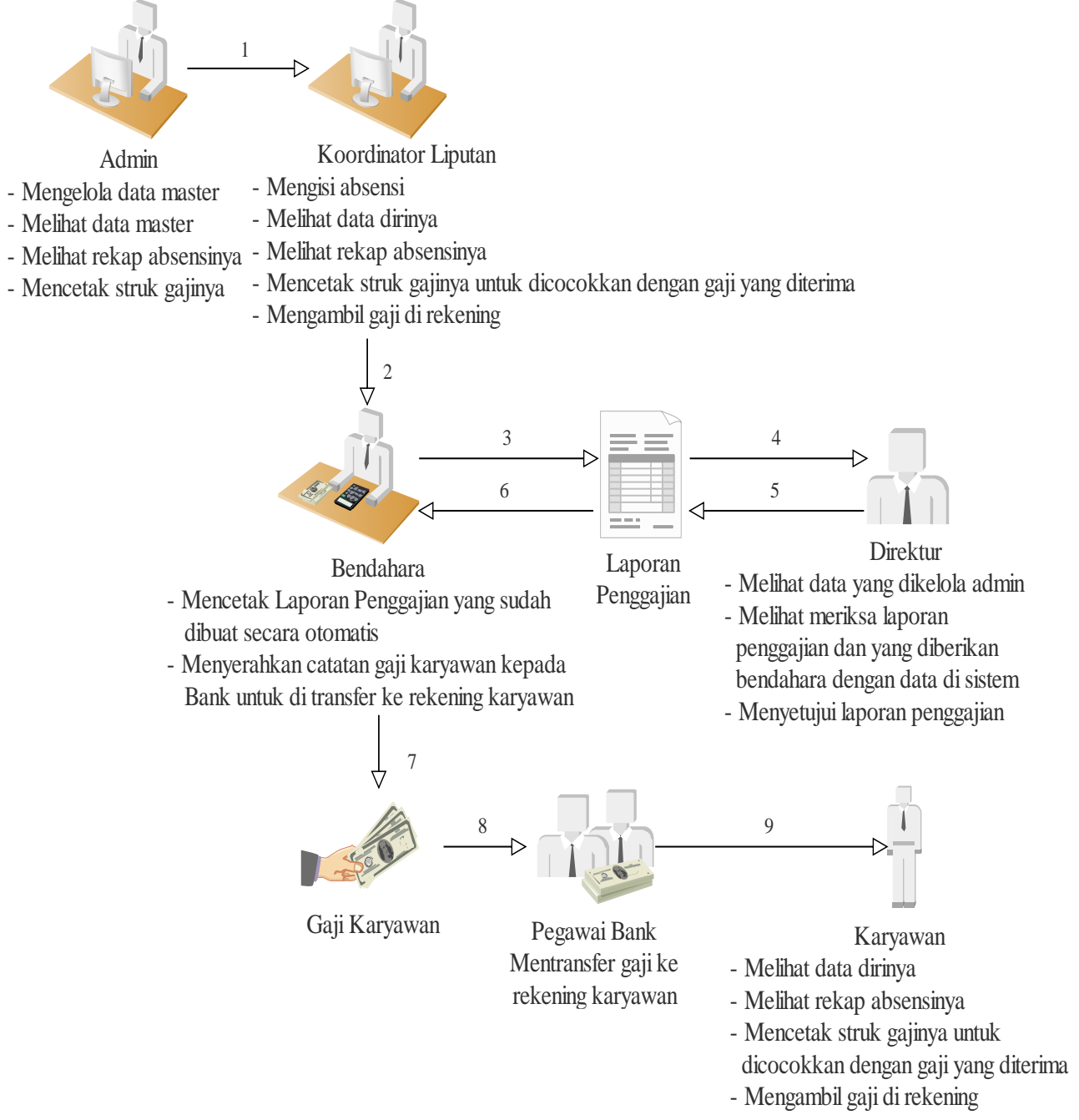

Gambar 2. Rich Picture Sistem Usulan 
Sistem informasi penggajian yang dirancang mendukung tugas dari:

a) Admin menggunakan sistem ini untuk mengelola file data master.

b) Karyawan menggunakan sistem ini untuk melihat data jabatannya, data jenis tunjangan, data tunjangannya, rekap absensinya, data dirinya, serta melihat dan mencetak slip gajinya.

c) Koordinator liputan menggunakan sistem ini untuk mengisi absen seluruh karyawan dan melihat rekap absen masing-masing karyawan, melihat data jabatannya, data jenis tunjangan, data tunjangannya, data dirinya, serta melihat dan mencetak slip gajinya.

d) Bendahara menggunakan sistem ini untuk melihat data jabatan, data jenis tunjangan, data seluruh karyawan, data tunjangan semua karyawan, melihat dan mencetak laporan absensi, melihat dan mencetak laporan penggajian, sebab perhitungan absensi dan gaji sudah terotomatisasi sistem.

e) Direktur menggunakan sistem ini untuk melihat data jabatan, data jenis tunjangan, data seluruh karyawan, data tunjangan semua karyawan, melihat dan laporan absensi, melihat laporan penggajian, sebab perhitungan absensi dan gaji sudah terotomatisasi sistem.

\section{Use Case Diagram}

Rancangan Use Case Diagram dapat dilihat sebagai berikut:

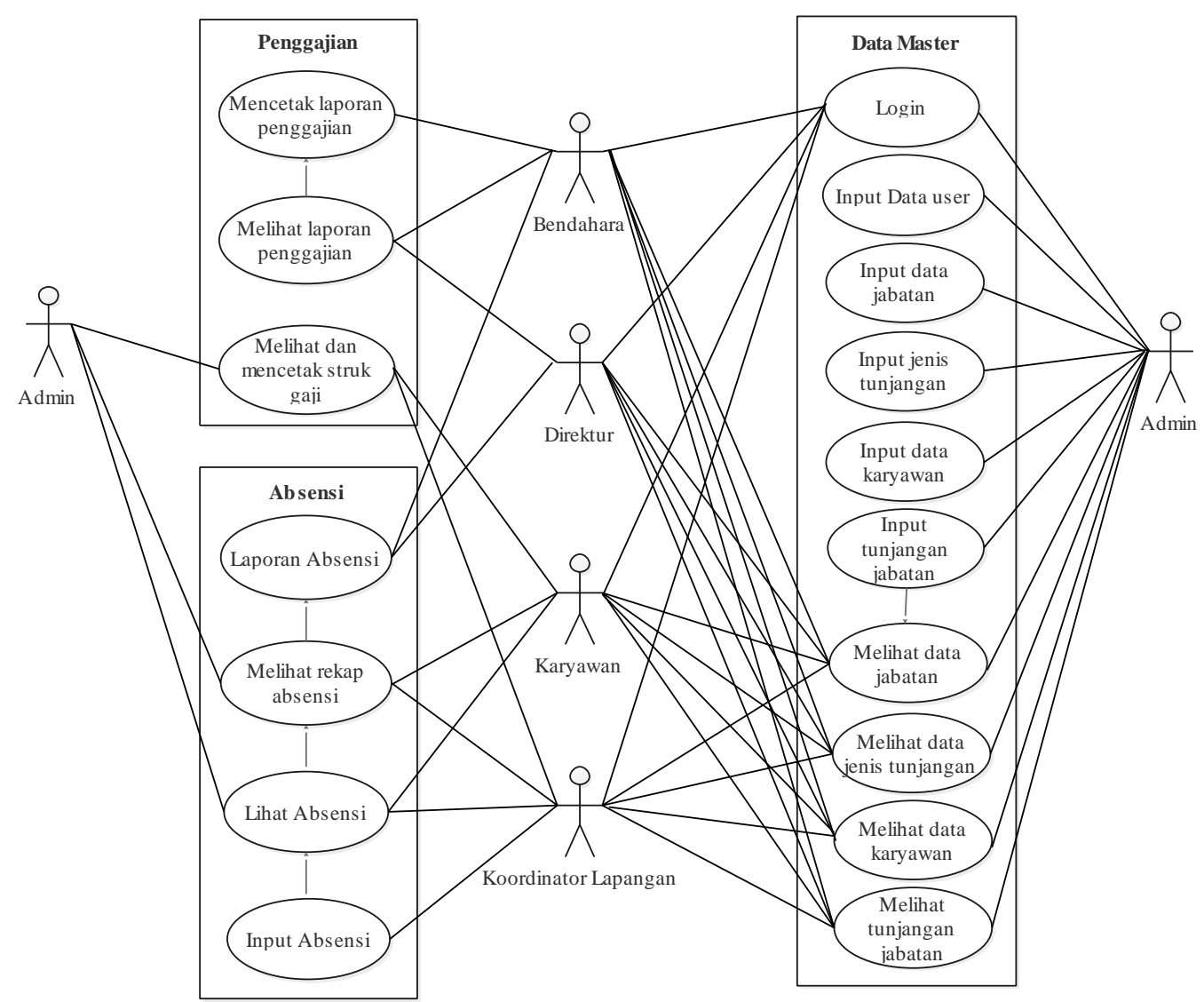

Gambar 3. Use Case Diagram

Berdasarkan gambar di atas, dapat disimpukan bahwa semua actor pada use case berperan sesuai dengan hak akses yang dimilikinya. 


\section{User Interface}

Beberapa tampilan user interface dari sistem informasi yang dibangun yaitu:

a) Menu Login

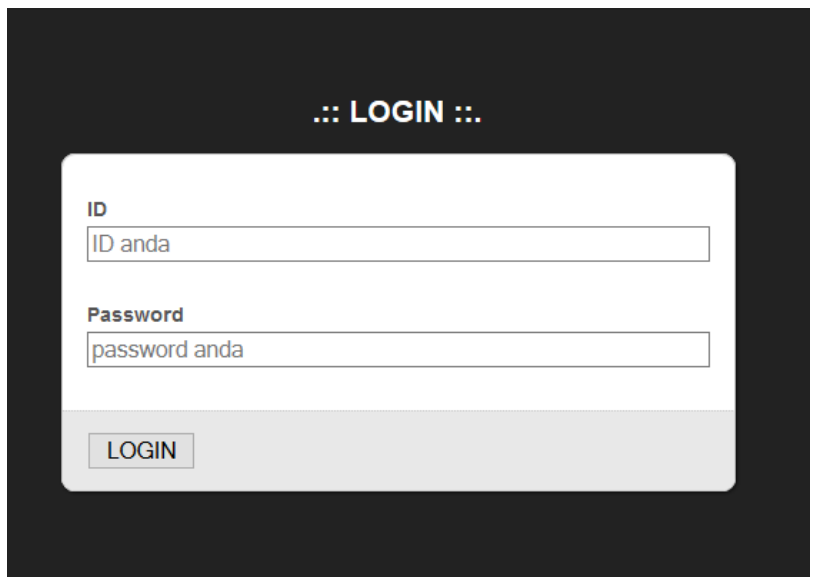

Gambar 4. Menu Login

Untuk mengakses sistem informasi penggajian, actor harus mengisikan ID dan password terlebih dahulu. Apabila ID dan passwordnya sesuai maka sistem akan berhasil login.

b) Halaman Menu

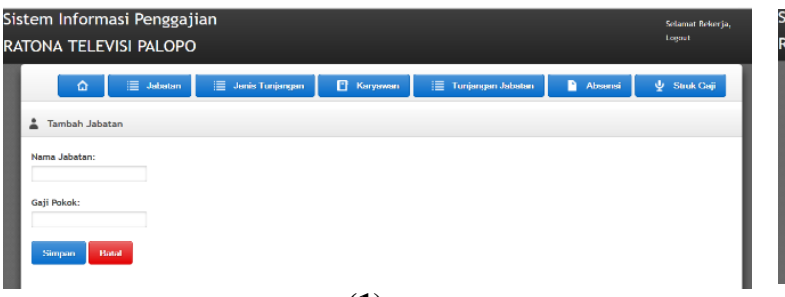

(1)

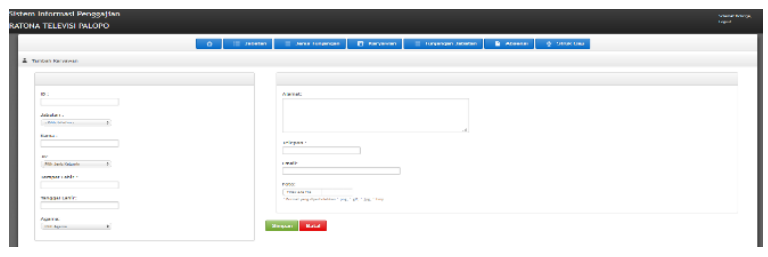

(3)

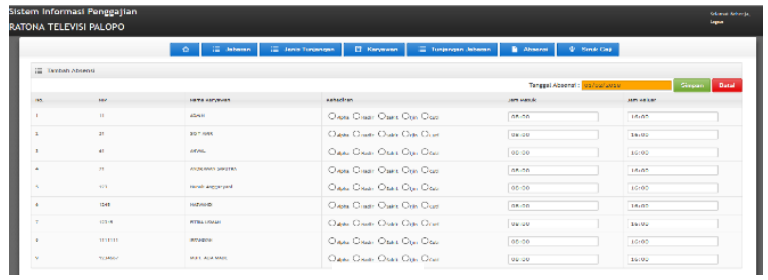

(5)

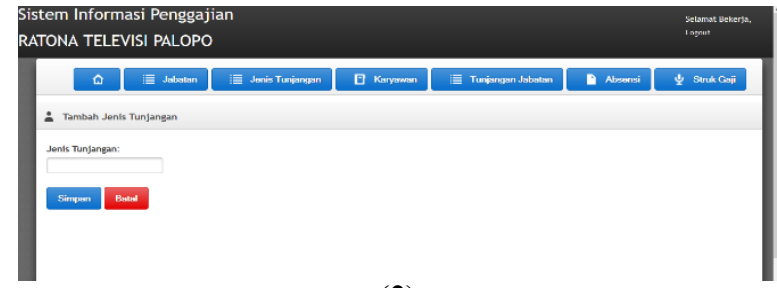

(2)

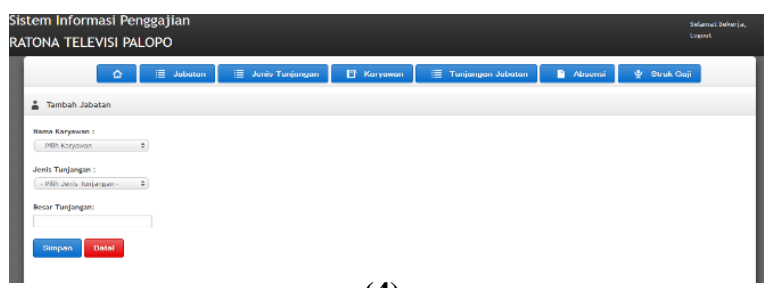

(4)

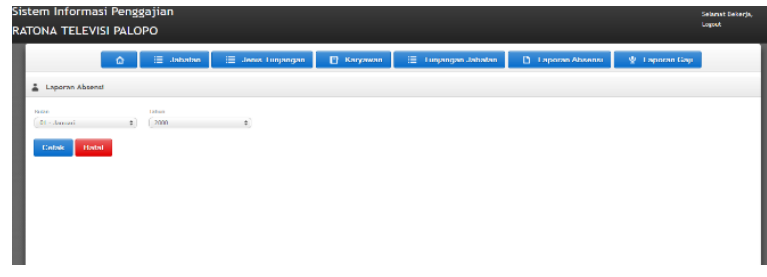

(6)

Gambar 5. Halaman Menu

Pada gambar di atas ditampilkan beberapa halaman menu yang terdapat di dalam sistem informasi yaitu: (1)halaman input data jabatan, (2)halaman input data jenis tunjangan, (3)halaman input data karyawan, (4)halaman input data tunjangan jabatan, (5)halaman input data agensi, dan (6)halaman melihat laporan absensi. 


\section{Testing}

Pengujian sistem penggajian informasi penggajian ini dilakukan dengan menggunakan metode black-box testing. Pengujian ini dimaksudkan untuk mengetahui apakah output yang dihasilkan dari sistem benar-benar sesuai dengan output yang diharapkan oleh pengguna sistem informasi penggajian.

Tabel 2. Testing

\begin{tabular}{|c|c|c|c|c|}
\hline No. & Rancangan Proses & Hasil yang Diharapkan & Hasil & Keterangan \\
\hline 1. & $\begin{array}{l}\text { Input address aplikasi } \\
\text { http://localhost/penggajian }\end{array}$ & $\begin{array}{l}\text { Menampilkan halamanform } \\
\text { login }\end{array}$ & $\mathrm{OK}$ & \\
\hline 2. & $\begin{array}{l}\text { Mengisi ID, username, dan } \\
\text { klik tombol "Login". }\end{array}$ & $\begin{array}{l}\text { Masuk pada halaman utama } \\
\text { actor }\end{array}$ & OK & \\
\hline 3. & $\begin{array}{l}\text { Pilih Menu User lalu klik } \\
\text { "Tambah User" }\end{array}$ & $\begin{array}{l}\text { Menampilkan data } \text { user yang } \\
\text { telah ada lalu masuk pada } \\
\text { form tambah User }\end{array}$ & OK & $\begin{array}{c}\text { Data tersimpan di } \\
\text { database kemudian } \\
\text { ditampilkan di menu } \\
\text { User }\end{array}$ \\
\hline 4. & $\begin{array}{l}\text { Pilih menu Jabatan lalu } \\
\text { klik "Tambah Jabatan" }\end{array}$ & $\begin{array}{l}\text { Menampilkan data } \\
\text { jabatanyang telah ada lalu } \\
\text { masuk pada form tambah } \\
\text { Jabatan }\end{array}$ & $\mathrm{OK}$ & $\begin{array}{c}\text { Data tersimpan di } \\
\text { database kemudian } \\
\text { ditampilkan di menu } \\
\text { Jabatan }\end{array}$ \\
\hline 5. & $\begin{array}{l}\text { Pilih menu Jenis } \\
\text { Tunjangan dan klik } \\
\text { "Tambah Jenis Tunjangan" }\end{array}$ & $\begin{array}{l}\text { Menampilkan data jenis } \\
\text { tunjanganyang telah ada lalu } \\
\text { masuk pada form tambah Jenis } \\
\text { Tunjangan }\end{array}$ & $\mathrm{OK}$ & $\begin{array}{c}\text { Data tersimpan di } \\
\text { database kemudian } \\
\text { ditampilkan di menu } \\
\text { Jenis Tunjangan }\end{array}$ \\
\hline 6. & $\begin{array}{l}\text { Pilih menu Karyawan dan } \\
\text { klik "Tambah Jenis } \\
\text { Karyawan" }\end{array}$ & $\begin{array}{l}\text { Menampilkan data } \\
\text { karyawanyang telah ada lalu } \\
\text { masuk pada form tambah } \\
\text { karyawan }\end{array}$ & $\mathrm{OK}$ & $\begin{array}{c}\text { Data tersimpan di } \\
\text { database kemudian } \\
\text { ditampilkan di menu } \\
\text { Karyawan }\end{array}$ \\
\hline 7. & $\begin{array}{l}\text { Pilih menu Tunjangan } \\
\text { Jabatan dan klik "Tambah } \\
\text { Tunjangan Jabatan" }\end{array}$ & $\begin{array}{l}\text { Menampilkan data tunjangan } \\
\text { jabatanyang telah ada lalu } \\
\text { masuk pada form tambah } \\
\text { Tunjangan Jabatan }\end{array}$ & OK & $\begin{array}{l}\text { Data tersimpan di } \\
\text { database kemudian } \\
\text { ditampilkan di menu } \\
\text { Tunjangan Jabatan }\end{array}$ \\
\hline 8. & $\begin{array}{l}\text { Pilih menu Absensi } \\
\text { a. Klik "Tambah } \\
\text { Absensi" } \\
\text { b. Klik "Lihat Absensi" } \\
\text { c. Klik "Rekap Absensi" }\end{array}$ & $\begin{array}{l}\text { Menampilkan data karyawan } \\
\text { yang memiliki absensi } \\
\text { a. Menampilkan form } \\
\text { tambah absensi } \\
\text { b. Menampilkan absensi } \\
\text { harian karyawan } \\
\text { c. Menampilkan rekap } \\
\text { absensi karyawan }\end{array}$ & OK & $\begin{array}{c}\text { Data tersimpan di } \\
\text { database kemudian } \\
\text { ditampilkan pada absensi } \\
\text { harian dan rekap absensi } \\
\text { karyawan }\end{array}$ \\
\hline 9. & $\begin{array}{l}\text { Pilih menu Struk Gaji } \\
\text { a. Klik cetak struk gaji } \\
\text { lalu pilih bulan dan } \\
\text { tahun yang ingin } \\
\text { dicetak lalu klik } \\
\text { "Cetak" }\end{array}$ & $\begin{array}{l}\text { Menampilkan data karyawan } \\
\text { a. Menampilkan struk gaji } \\
\text { karyawan pada bulan dan } \\
\text { tahun yang dipilih }\end{array}$ & $\mathrm{OK}$ & \\
\hline 10. & $\begin{array}{l}\text { Pilih menu Laporan } \\
\text { Absensi lalu pilih bulan } \\
\text { dan tahun yang ingin } \\
\text { dicetak lalu klik "Cetak" }\end{array}$ & $\begin{array}{l}\text { Menampilkan laporan absensi } \\
\text { semua karyawan pada bulan } \\
\text { dan tahun yang dipilih }\end{array}$ & $\mathrm{OK}$ & \\
\hline 11. & $\begin{array}{l}\text { Pilih menu Laporan Gaji } \\
\text { lalu pilih bulan dan tahun } \\
\text { dan klik "Cetak" }\end{array}$ & $\begin{array}{l}\text { Menampilkan laporan gaji } \\
\text { semua karyawan pada bulan } \\
\text { dan tahun yang dipilih }\end{array}$ & OK & \\
\hline
\end{tabular}




\section{Validasi Sistem}

Aspek-aspek yang diperhatikan dalam menvalidasi sistem informasi penggajian adalah kemanfaatan, kualitas tampilan dan pengoperasian. Hasil validasi dari ahli telah dirangkum pada tabel di bawah ini:

Tabel 3. Validasi Sistem Informasi Penggajian

\begin{tabular}{cccc}
\hline No & Aspek penilaian & M & Ket \\
\hline 1 & Kemanfaatan & 3,7 & SV \\
2 & Tampilan & 3,25 & V \\
3 & Pengoperasian & 3,56 & SV \\
\hline & Rata-rata penilaian total & $\mathbf{3 , 5}$ & SV \\
\hline
\end{tabular}

Adapun diagram batangnya dapat dilihat pada gambar berikut:

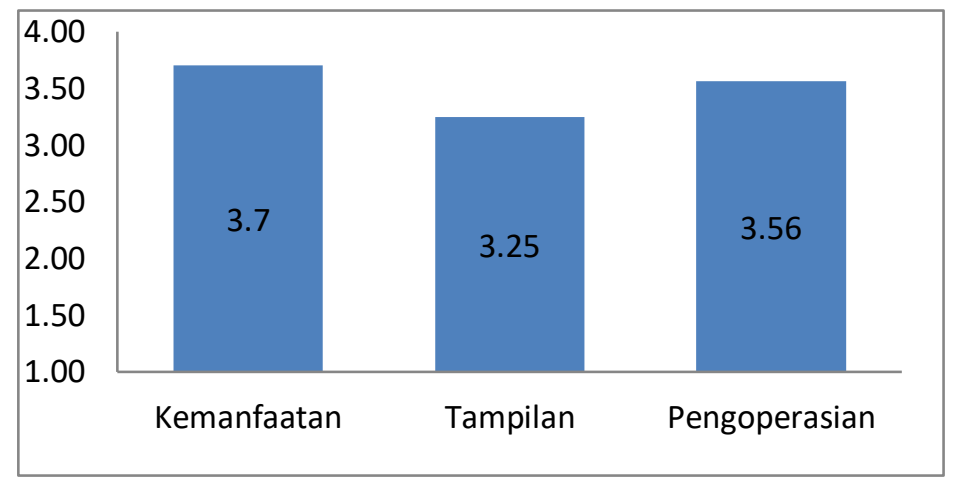

Gambar 5. Diagram Batang Hasil Validasi berikut:

Hasil analisis yang ditunjukkan pada Tabel di atas dapat dijelaskan sebagai

a) Nilai rata-rata kevalidan sistem informasi penggajian karyawan Ratona TV berdasarkan aspek kemanfaatan adalah $\mathrm{M}=3,7$. Berdasarkan kriteria kevalidan nilai ini termasuk dalam kategori sangat valid (SV) yaitu berada pada $(3,5 \leq \mathrm{M} \leq$ 4). Jika ditinjau dari aspek format maka sistem informasi penggajian ini dapat dinyatakan memenuhi kriteria kevalidan.

b) Pada aspek tampilan nilai rata-rata kevalidan sistem informasi penggajian adalah $\mathrm{M}=3,25$. Berdasarkan kriteria kevalidan, termasuk dalam kategori sangat valid "V" karena berada pada $(2,5 \leq \mathrm{M}<3,5)$, sehingga dapat dinyatakan memenuhi kriteria kevalidan.

c) Pada aspek pengoperasian tampilan nilai rata-rata kevalidan sistem informasi penggajian adalah $\mathrm{M}=3,56$. Berdasarkan kriteria kevalidan, termasuk dalam kategori sangat valid "V" karena berada pada $(3,5 \leq M \leq 4)$, sehingga dapat dinyatakan memenuhi kriteria kevalidan.

Selanjutnya dilakukan analisis respon. Tujuan analisis data respon adalah juga untuk melihat bagaimana respon pihak Ratona TV terhadap sistem informasi penggajian karyawan yang telah dikembangkan. Hasil analisis tersebut ditunjukkan pada Tabel berikut: 
Tabel 4. Analisis Respon Sistem Informasi Penggajian

\begin{tabular}{|c|c|}
\hline Pernyataan & $\begin{array}{c}\text { Persentase Skor } \\
(\%)\end{array}$ \\
\hline $\begin{array}{l}\text { 1. Sistem informasi ini dapat membantu dalam proses } \\
\text { penggajian anda }\end{array}$ & 100 \\
\hline $\begin{array}{l}\text { 2. Dapat membantu dalam memberikan informasi tentang } \\
\text { gaji dan absensi anda }\end{array}$ & 98,3 \\
\hline 3. Sistem informasi ini mudah untuk diakses & 100 \\
\hline 4. Informasi yang disediakan sistem mudah dimengerti & 98,3 \\
\hline 5. Informasi yang diberikan tergolong lengkap & 93,3 \\
\hline $\begin{array}{l}\text { 6. Akses informasi dapat dilakukan dimana saja asal } \\
\text { terkoneksi internet }\end{array}$ & 96,7 \\
\hline $\begin{array}{l}\text { 7. Menu-menu yang disediakan sudah sesuai dengan } \\
\text { kebutuhan pengguna }\end{array}$ & 95 \\
\hline 8. Komposisi ukuran tulisan pada aplikasi sudah baik & 88,3 \\
\hline 9. Sistem informasi bermanfaat bagi pengguna & 100 \\
\hline 10. Tulisan pada aplikasi dapat saya baca secara baik & 93,3 \\
\hline 11. Komposisi warna yang digunakan menarik & 80 \\
\hline 12. Komposisi background yang digunakan menarik & 80 \\
\hline 13. Informasi pada struk gaji karyawan sudah sesuai & 93,3 \\
\hline 14. Secara keseluruhan sistem memuaskan bagi pengguna & 95 \\
\hline $\begin{array}{l}\text { 15. Bahasa yang digunakan dalam aplikasi mudah } \\
\text { dipahami }\end{array}$ & 100 \\
\hline Persentase Rata-rata (\%) & 94 \\
\hline
\end{tabular}

Hasil analisis respon karyawan pada tabel diatas menunjukkan karyawan memberikan respon positif kepada sistem informasi penggajian. Hal ini dapat dilihat pada nilai persentase total rata-rata tiap kriteria yang dinilai. Adapun rata-rata total yang menggambarkan aspek praktikalitas adalah $94 \%$ yang mengindikasikan bahwa sistem informasi penggajian sangat baik.

\section{KESIMPULAN}

Berdasarkan hasil pembahasan pengembangan sistem informasi penggajian yang telah dilakukan, maka dapat diperoleh kesimpulan sebagai berikut:

a) Sistem informasi penggajian yang dibuat telah terkomputerisasi secara online, efektif, bermanfaat dan mempermudah pengolahan data penggajian.

b) Sistem informasi penggajian yang dibuat tergolong praktis bagi karyawan Ratona TV Palopo.

\section{DAFTAR PUSTAKA}

Asrozi, 2011. "Pengembangan Sistem Informasi Penggajian KaryawanPada BMT Berkah Syariah. Fakultas Sains dan Teknologi UIN Syarif Hidayatullah, Jakarta.

Kadir, Abdul, 2014. "Pengenalan Sistem Informasi". Edisi revisi. Andi offset, Yogyakarta.

Prasetyo, Sigit, 2011. "Pengembangan Sistem Informasi Penggajian. (Studi kasus: SMK Al-Firdaus)". Fakultas Sains dan Teknologi UIN Syarif Hidayatullah, Jakarta. 
Sodikin, 2011. "Perancangan Sistem Penggajian dengan Hak Akses Karyawan Berbasis Web. (Studi Kasus: PK Gaya Baru). Fakultas Sains dan Teknologi UIN Syarif Hidayatullah, Jakarta.

Zulnalis, 2016. "Sistem Informasi Penggajian Karyawan. Studi kasus: PT. Arul Global Sec urity Service Jakarta”. VOL.V No.2 Agustus 2016, ISSN 2089-8711. 
PENA TEKNIK: Jurnal Ilmiah Ilmu-Ilmu Teknik

Volume 3, Nomor 2, September 2018 : 147 - 156

Halaman ini sengaja dikosongkan 